\title{
FORMULA GRANTS TO SCHOOLS OF PUBLIC HEALTH*
}

\author{
By Myron E. Wegman, M.D., M.P.H. ${ }^{* *}$
}

The Editor is pleased to find a dean of a school of public health
willing to present so forthrightly
the problems now facing educators of public health personnel.

As the dean of one school of public health and as the Past President and current Chairman of the Legislative Committee of the Association of Schools of Public Health, I feel that I can speak from some experience about the federal assistance which regional schools of public health in this country require to continue the education of health personnel for the public. My Association includes all 16 university schools in the United States-California at Berkeley, California at Los Angeles, Columbia, Harvard, Hawaii, Johns Hopkins, Loma Linda, Michigan, Minnesota, North Carolina, Oklahoma, Pittsburg, Puerto Rico, Texas, Tulane, and Yale. I am appearing in support of the legislation to extend and increase the authorization for formula grants to schools of public health under Section 309(e) of the Public Health Service Act.

Although not changed in basic purpose and orientation, public health has changed significantly in scope and content in just the past few years. The Congress has created a series of programs aimed at improving the health of the American people, programs which, if well administered and staffed, hold great promise for the prevention of disease and for a better status of health. Medicare and Medicaid are well known and obvious examples, but emphasis on health factors also has been a prominent aspect in the OEO programs and Model City programs. The 1967 and 1968 legislation for comprehensive health planning is a major landmark in support of the principle for considering all possible factors before allocations for health are made. Here are major implications for an eventual cutting of costs and for obtaining more value from public dollars spent for health.

All the old and new health programs not only require large increases in prepared personnel but the tasks to be carried out require the type of education best provided in a multidisciplinary setting. For example, senior planning officials need to know the biological back-ground of disease in order to understand how both personal factors and the influence of the physical environment affect health goals. They have to be familiar with the same background to appreciate the possibilities which reasonably may be expected of organized preventive health measures. At the same time, planners must understand organizational principles, the technics of gathering data for economic decisions, and the possibilities and limitations of applying a cost-benefit analysis to a health situation. Proper education in these various factors should produce health personnel capable of planning more effective and economical distribution of public resources in the future. Other examples are the physician and nurse able to direct health programs in areas of poverty where they need to know the social, behavioral, and environmental aspects that are associated.

The variety of persons just mentioned constitute a small sample only of the kinds of personnel preparcd at schools of public health. Schools of public health received their

\footnotetext{
*Testimony submitted to the Committee on Interstate and Foreign Commerce of the House of Representatives in December, 1969.

**Dean, School of Public Health, The University of Michigan, Ann Arbor, Michigan, 48104.
} 
impetus in the famous Welch-Rose report of 1915, which concluded that solution of the major public health problems of the day-the communicable diseases-required more than medical and nursing skills and more than just adding to these specialties a corps of other specialists. Dr. Welch and Mr. Rose noted particularly the importance of environmental factors and the problems of organization and of public administration.

The school of public health was established as an institution in this country where physicians, engineers, political scientists, nurses, and others could take part as faculty members and as students. The goal always has been a solid base in both the natural sciences and the social sciences, for a broad program of multidisciplinary education and research. What has perhaps not been emphasized enough is the readiness with which schools of public health have changed to meet new community needs. Since the WelchRose report, for example, great progress has been achieved in the relative decline of communicable diseases as causes of death and disability. While insisting that the danger or resurgence of communicable diseases, along with the presence of many still unconquered diseases, requires continuing research for new vaccines and new methods of protection, the schools steadily and progressively have devoted much more energy to the chronic diseases and to the maintenance of health. Technics successful in studying the spread of smallpox, diphtheria, and typhoid also can be adapted to the study of the factors that influence the development and distribution of heart disease and cancer. It might be noted that the largest single project of research at my own school of public health is a continuing survey of an entire city in an attempt to identify the precursors of heart disease and the factors which affect its occurence.

As the concept of prevention has broadened, every school today is more than ever concerned in teaching and research for improving the organization of health services and for ways to improve the allocation of the community's resources among its health problems-comprehensive health planning.

In a closely related subject the schools are working intensively on the problems of limiting population. My own university is one example; it has three closely interrelated centers, the Population Studies Center in the Department of Sociology, the Center for Research on Reproductive Biology in the Department of Obstetrics and Gynecology, and the Center for Population Planning in the School of Public Health. The School of Public Health is concentrating on the ways to achicve successful programs of action.

Growth in population is closely connected with human nutrition, an area in which schools such as Harvard, Columbia, Johns Hopkins, Tulane, and Minnesota have developed outstanding programs.

All schools currently are giving increased emphasis to the environment. Supply ing water and controlling sewage have been central interests of public health since the earliest days; the problems of polluted air and protection against ionizing radiation are now increasingly prominent.

Some index of the scope of a school of public health in 1969 may be gained from listing the programs of study offered at one university. I cite again The University of Michigan, since I know it best, but similar statements could be made for the other schools. (See Table 1)

One reflection of recent change can be seen in two of the listed programs-Medical Care Organization and Population Planning. In 1961-62 Medical Care Organization had four students who were studying for the degree Master of Public Health and in 1968-69 the number had increased to 39. Population Planning began as a program of study in 1966, but by 1969 had 36 enrollees seeking either the degree at the master's level or the doctoral degree.

In two other specific ways schools of public health emphasize their multidisciplinary, natural science-social science character: they (1) mix student backgrounds and (2) present a common core of instruction. The first is well illustrated in the last report of the 
Table 1

The Concerns of Public Health

\begin{tabular}{ll}
\hline Air Pollution & Industrial Hygiene \\
Biostatistics & Maternal and Child Health \\
Chronic Diseases, Adult Health, and Aging & Medical Care Organization \\
Dental Public Health & Mental Health \\
Environmental Health-Food Contacts & Nutrition \\
Environmental Health-General & Occupational Medicine \\
Environmental Health-Water Contacts & Population Planning \\
Epidemiology & Public Health Administration \\
Health Education & Public Health Laboratory Practice \\
Health Planning & Public Health Nursing \\
Hospital Administration & Radiological Health \\
\hline
\end{tabular}

Committee on Professional Education of the American Public Health Association, the accrediting body for schools of public health. Among the 22 widely disparate specified professional groups studying at schools of public health, significant numbers of administrators, dentists, engineers, laboratory scientists, nurses, physicians, and teachers will be found. Such a varied background brings strength as well as problems. Students contribute to each other's education but the difference in prior preparation makes it much more difficult to organize a high-level stimulating educational program, without having it too easy for some and too advanced for others. Secondly, all students, whatever their background and whatever their specific field of interest, take part in a common educational program designed to ensure that all students have an understanding of (1) the nature of man, his physical and social environment, and his personal and social interactions as they affect his health; (2) the basic technics of investigation, measurement, and evaluation which include the biostatistical treatment of data, and the principles that guide epidemiological research; (3) the basic technics of administration (organization and management), particularly applicable to programs of comprehensive health care; (4) the economic and political settings relevant to health services; and (5) the application of these knowledges in the promotion of community health.

At my school this team-understanding is achieved through a common, integrated core course. At other schools it may take the form of a series of related courses. The objective in all schools is the same; it takes advantage of the uniquely broad setting of the school of public health to provide for its students, from a wide variety of previous training and interests, both a common basis in public health and a preparation in some depth for those interested in a specific phase.

The setting for these types of education is both complicated and costly. In the earlier years state and private support carried the burden, but the rapidly changing situation a decade ago led to the legislation which the Committee now is considering for extension. The original impetus came because the Federal Government, to meet growing demands for manpower, was supporting training at schools of public health for an increasingly large group of students, while the tuition paid on behalf of these students was far short of covering the costs to the school for this type of education. Simply stated, the formula grants attempted to compensate in part for the unmet educational costs that the Government was creating. The original legislation had extensive bipartisan support in both Houses of Congress and was passed unanimously. Since then it has been extended periodically and has become an ever more vital part of the operations of the various schools.

It must be emphasized that the 16 schools of public health, nine of which are in state universities, have the responsibility for providing graduates capable of duty in the health services of all 50 states, the territories, and the Federal Government, as well as for 
the international activities of the United States and the international agencies. Each school, therefore, has to be concerned with an area far beyond that of the ordinary range of influence of its university. Schools of public health, in this way, are analogous to national service academies in that they must prepare students for public service anywhere in the country. This point is of particular significance for the state schools, since state legislatures, faced with mounting costs in all activities, customarily restrict out-of-state registrants sharply. My own university, for example, long has had a tradition of admitting a substantial number of students from outside the State of Michigan, but in this century the proportion of such students has gradually decreased to a current University average of approximately 25 percent. In the School of Public Health, on the other hand, the ratio is reversed and two-thirds to three-quarters of the students come from outside the state. One can understand the reluctance of a state's legislature, under such circumstances, to make a substantial investment in a faculty and facilities that will benefit nonresidents chiefly. In the private universities, while the out-of-state problem is of no concern, endowments just are insufficient to meet mounting costs.

A corollary is that, unlike some of the educational programs leading to qualification of individual practitioners, the professional person in public health must perforce, with few exceptions, look forward to a career as a salaried person in an agency, public or private, but devoted to public service. Such careers are not highly remunerated, hence students are less willing to subsidize their own graduate education or be ready to pay personally for the high cost of operations. Schools of public health, all at the graduate level, cannot look forward to the kind of contributions from alumni which often form such an important part of the resources of other academic schools.

Conscious that legislation to provide Federal formula grants has played such a key-role during the past 11 years, the Association of Schools of Public Health undertook, in the spring of 1969 , an extensive study of the progress accomplished with the aid of these grants. I ask permission to make the detailed report of this study a part of the record of these hearings.

The revealing results of the study may be summarized under several headings: productivity, costs, and future needs. The figures for productivity are striking, in the light of the fundamental aim of the legislation to increase the number of properly prepared professional personnel. At the time that the original legislation was enacted there were 11 accredited schools of public health. During the ten-year period, 1948-1957 prior to the program of formula grant, some 6,400 degrees were awarded in these schools. In the 10 subsequent years, as the formula grants made possible expansion in existing schools and the advent of four more schools (The University of Texas School of Public Health has not yet graduated its first class), almost twice as many degrees were earned. Of even more significance during this period, has been an even greater increase in enrollment, almost two and a half times, to promise a further increase in graduates. Detailed analysis shows, moreover, that the increases since 1963, after the formula grants had some time to make their effect felt, has been even more striking. In fact, the bulk of the increase, both in degrees awarded and in the size of the student body, has taken place in the period between 1963 and 1969.

The study reveals further that more than 90 percent of graduates enter public service and that they hold the key-posts in local, city, state, national, and international agencies. The character of professional leadership in the teaching of public health in the United States has been reflected in the frequency with which faculty members are requested for consultation abroad. Schools of public health in the American pattern, moreover, have been formed in many countries elsewhere in the world, and made it possible for students of those countries to see the principles applied directly that were taught in the schools of the United States.

In the ycars since the legislation for formula grants first was passed, the activities of the Federal Government in sponsoring students at schools of public health have grown 
ever more markedly. In 1963, 56 percent of all students in that year's 12 schools of public health were sponsored by the Federal Government. In 1968, however, by which time the total enrollment in schools of public health had doubled, the proportion of federally-sponsored students had grown even more rapidly, to a total of 67 percent, which throws a greatly increased burden on the schools.

The Congress has been mindful of this increase and, as shown in Table II, authorizations have been increased in accordance with demonstrated need. Appropriations, unfortunately, have not increased concomitantly so that serious gaps now exist. My Association, of course, is bringing this situation forcefully to the attention of the Appropriations Committee.

While the support of the formula grants has been most helpful, serious shortcomings still exist for, as is obvious from the general financial situation of our country, costs in all of the universities have risen sharply. Between 1963 and 1968 the total student body doubled, but the cost of basic operations and teaching, excluding sponsored research, increased almost threefold. Despite the increase in actual amounts received by the schools of public health under the formula grants, the increase met only 12 percent of the cost of basic teaching in 1968 as against 16 percent five years earlier. The greater numbers of federally-sponsored students were, in fact, throwing an ever increasing burden on other sources of revenue.

Table II

\begin{tabular}{|c|c|c|c|}
\hline \multicolumn{3}{|c|}{$\begin{array}{c}\text { Formula-Grant Assistance to Schools of Public Heaith-Amounts Authorized } \\
\text { and Appropriated by Congress - Fiscal Years }\end{array}$ 1959-1970 } \\
\hline $\begin{array}{c}\text { Fiscal Year } \\
\text { Ending June 30 }\end{array}$ & $\begin{array}{c}\text { Number of } \\
\text { Schools }\end{array}$ & $\begin{array}{c}\text { Amounts } \\
\text { Authorized }\end{array}$ & $\begin{array}{c}\text { Amounts } \\
\text { Appropriated }\end{array}$ \\
\hline 1959 & 11 & $\$ 1,000,000$ & $\$ 450,000$ \\
1960 & 12 & $1,000,000$ & $1,000,000$ \\
1961 & 12 & $1,000,000$ & $1,000,000$ \\
1962 & 12 & $2,500,000$ & $1,900,000$ \\
1963 & 13 & $2,500,000$ & $1,900,000$ \\
1964 & 13 & $2,500,000$ & $1,900,000$ \\
1965 & 13 & $2,500,000$ & $2,500,000$ \\
1966 & 14 & $5,000,000$ & $3,500,000$ \\
1967 & 14 & $5,000,000$ & $3,750,000$ \\
1968 & 15 & $5,000,000$ & $4,000,000$ \\
1969 & 15 & $6,000,000$ & $4,554,000$ \\
1970 & 16 & $7,000,000$ & $4,554,000$ \\
\hline
\end{tabular}

In its survey, my Association completed an analytical review of the individual schools to disclose their current greatest needs and their most critical shortcomings. The results showed, to fill existing serious gaps in faculty positions and to take carc of the anticipated student-load, that $\$ 12.5$ million will be needed in fiscal year 1971 , in fiscal year $1972, \$ 16.8$ million, and in fiscal year $1973, \$ 21.6$ million. The figures contained in the bills under consideration by this Committee, hence, are realistic approximations, even if they will not satisfy needs fully.

The Committee will be interested to know that the kinds of programs of teaching cited by the schools as needing the chief help are the basic ones required for preparing the bulk of health personnel still sought by the operating health agencies. The programs include health administration and comprehensive health planning, the epidemiology of acute and chronic discase, and the environmental aspects of health. They also include the 
problems of ionizing radiation and of occupational health. These three broad fields do not have the drama of a transplanted heart, but more effective teaching of basic concepts and principles unquestionably will result in saving many more lives, in preventing more disability, and in helping more people to an effective and productive existence.

of ionizing radiation and of occupational health. These three broad fields do not have the drama of a transplanted heart, but more effective teaching of basic concepts and principles unquestionably will result in saving many more lives, in preventing more disability, and in helping more people to an effective and productive existence.

Another major interest of the schools, crying for further development, is continuing education. With the rapid advance of scientific and technical knowledge practitioners in any specialized field quickly can get out of date. Several of the schools of public health long have followed the practice of using part of their resources to provide short courses for practitioners in order to bring them up to date and to introduce them to new areas of knowledge. The demand from health agencies for such courses far outstrips the supply. A number of the schools would like to expand into this activity if funds, such as those under the formula grant, could be found for faculty and the necessary supplies. I shall not try to list the other subjects mentioned in detail in the report but shall note that important Congressional priorities, such as population, family planning, maternal and child health, and health education are high on the list.

A key-factor in relation to need is the establishment of new schools. I remind the Committee that the regulations for administering the legislation which permits the formula grants, provides for division of one-third of the appropriation equally among all accredited schools and for division of the other two-thirds in proportion to the number of federally-sponsored students enrolled in each school. Whenever a new school is accredited, therefore, the immediate result is a decrease in the allocation to every other school, unless the total appropriation is increased. It appears at the present moment that another decrease will occur this year since the new School of Public Health at the University of Texas was accredited in June, 1969, and now is entitled to participate in this year's appropriation, unchanged from last year in the budget now before the Congress. The University of Texas has plans for rapid growth and expansion so that its allocation in proportion to the number of federally-sponsored students also will increase. It hardly seems logical to encourage a new school to start operation in order to provide needed manpower when fiscal policy forces the existing schools to contract.

At least two other schools are in the immediate offing. The Regents of the University of Illinois have announced their intention to establish a school of public health and the University of Alabama is working in that direction. Word has been received that the University of Washington and the University of Cincinnati seriously are considering the development of full-scale schools of public health. Our Association is pleased to learn of these developments because the advent of new schools makes for greater strength in all schools. The Association thinks, nevertheless, that the situation necessitates Congressional action urgently.

I should like to close by reaffirming my point that schools of public health are unique in their concentration on preparing personnel for public service, for their multidisciplinary character, in the small number of schools with responsibility for meeting the needs of the whole country, and with the anomalous situation in that two-thirds of all students are sent to the schools under the auspices of the Federal Government, yet the Federal Government is paying tuition that covers a small part only of the basic cost of this education. I urge upon the Committee approval of the authorizations requested in these bills I think that the documentation is completely adequate to support authorization for a five-year period. 